Violeta Orlović - Lovren', Aleksandra Pejatović ${ }^{2}$

UDK: 374.7-053.88:331.5(497.11)

$331.56(497.11)$

\title{
OBRAZOVANJE ODRASLIH - PUT IZLASKA IZ ZAČARANOG KRUGA NEZAPOSLENOSTI I SOCIJALNE IZOLACIJE STARIJIH OSOBA? ${ }^{3}$
}

\section{- Sažetak -}

Kontinuirani porast nezaposlenosti, karakterističan za mnoga evropska društva danas, u Srbiji nosi i breme specifične, dugogodišnje krize, čiji su efekti pojačani svetskom ekonomskom krizom, krajem prethodne decenije. Jaz između strateških opredeljenja prema doživotnom obrazovanju kao moćnom mehanizmu redukcije nezaposlenosti i prakse posebno je vidljiv kada je reč o grupi starijih nezaposlenih.

Suočeni sa takvim trendovima, stručnjaci okupljeni oko Društva andragoga Srbije pokrenuli su 2012. godine projekat „Obrazovanjem ka zapošljavanju i aktivnom starenju”, sa ciljem da se, u sklopu mera aktivnog zapošljavanja, doprinese unapređenju obrazovanja u Srbiji i povećanju zapošljavanja $i$ zapošljivosti odraslih starijih od 50 godina.

1 Dr. Violeta Orlović-Lovren, docent na Filozofskom fakultetu Univerziteta u Beogradu, na Odeljenju za pedagogiju i andragogiju. Unutar šire andragoške oblasti, posebno se bavi pitanjima didaktičkometodičkog pristupa učenju i poučavanju odraslih, andragoškom ulogom i razvojem nastavnika, kao i ekološkim aspektima obrazovanja odraslih. Kao konsultant, angažovana je u nizu timova u okviru domaćih i međunarodnih projekata. E-mail: orlovicvioleta08@gmail.com.

2 Dr. Aleksandra Pejatović radi kao docent na Filozofskom fakultetu Univerziteta u Beogradu, na Odeljenju za pedagogiju i andragogiju. U oblasti andragogije bavi se problemima stručnog obrazovanja odraslih, kvaliteta obrazovanja, ispitivanja obrazovnih potreba odraslih i karijernog savetovanja i vođenja. Učestvovala je na više projekata koje je finansirala Evropska unija i autor je većeg broja radova. E-mail: apejatov@f.bg.ac.rs.

3 Članak predstavlja rezultat rada na projektima:”Obrazovanjem ka zapošljavanju i aktivnom starenju", čiju realizaciju je finansirala Fondacija za otvoreno društvo, Srbija i 'Modeli procenjivanja i strategije unapređivanja kvaliteta obrazovanja u Srbiji”, broj 179060 (2011-2014), čiju realizaciju finansira Ministarstvo prosvete, nauke i tehnološkog razvoja Republike Srbije. 
U radu predstavljamo segment rezultata istraživanja na uzorku od 387 starijih nezaposlenih u pet gradova u Srbiji, starosti od 50 do 65 godina, različitog pola $i$ obrazovnog statusa. Posebno se izdvajaju nalazi koji govore o stavu nezaposlenih prema mogućnosti obrazovanja da ih povede ka zapošljavanju i prevazilaženju nepovoljnog socio-ekonomskog položaja, višestruko uzrokovanog uglavnom dugim stažom nezaposlenosti i postepenim isključivanjem iz društvenog života. Uočeni trendovi se sagledavaju u kontekstu specifičnih, ali $i$ globalnih društvenih okolnosti $i$ pravaca neophodnih unapređenja obrazovnih $i$ drugih rešenja na nivou politike $i$ prakse obrazovanja (odraslih) i zapošljavanja.

\section{Ključne reči: nezaposlenost, obrazovanje odraslih, stariji odrasli, dugoročna nezaposlenost starijih odraslih osoba.}

\section{Uvod}

Radi boljeg razumevanja i rezultata emprijskog istraživanja i, u radu načinjene, njihove analize, kojima su obuhvaćeni neki od aspekata međusobnog odnosa obrazovanja odraslih i dugoročne nezaposlenosti starijih osoba, valja svakako, bar sažeto, predstaviti kontekst u okviru kojeg je ovaj odnos istraživan. Pod kontekstom u ovom slučaju podrazumevamo aktuelno stanje u Republici Srbiji, odnosno, one elemente tog stanja koje bismo morali da imamo u vidu kada govorimo o navedenoj relaciji.

Osnovnu i opštu karakteristiku i stanja u Srbiji i vremenskog perioda koji započinje osamdesetih godina dvadesetog veka, koji još uvek traje, mogli bismo da okarakterišemo kao ,prolongirani krizni period”. Bilo da ga posmatramo kao period kontinuirane krize koja se na različite načine ispoljava ili kao period ispunjen i sukcesivnim i simultanim krizama vidljivim u različitim sektorima države i oblastima života stanovništva, a koje se međusobno umrežavaju, kao glavne elemente ,prolongiranog kriznog perioda” u Srbiji, između ostalih, mogli bismo da izdvojimo: ekonomsku krizu, raspad SFRJ, rat na teritorijama bivših jugoslovenskih republika, talase izbegličkog stanovništva, hiperinflaciju, sankcije međunarodne zajednice, intervenciju NATO snaga, započetu i do kraja nesprovedenu privrednu tranziciju, narastajuće siromaštvo stanovništva, porast nezaposlenosti, demografsko starenje stanovništva... (Pejatović, 2006). Imajući na umu pobrojane elemente, u potpunosti možemo da se saglasimo sa konstatacijom autora Nacionalnog izveštaja za Srbiju za CONFINTEA-u VI, da je sa ,(...) današnje tačke gledišta, sasvim (...) evidentno da su te godine (pre 2000, prim. Orlović-Lovren, Pejatović) bile 
više razarajuće nego propuštene, i to od razaranja bazične infrastrukture do ljudskih resursa" (Medić, Popović, Milanović, 2009: 1).

I pored duge tradicije, i na prostorima SFR Jugoslavije i na prostorima Srbije, ni obrazovanje odraslih nije moglo da izbegne uticaje navedenih neprilika. Među osnovnim karakteristikama prakse obrazovanja odraslih u Srbiji izdvajaju se: nestajanje ili transformacija većeg broja tradicionalnih institucija za obrazovanje odraslih (poput radničkih i narodnih univerziteta); jačanje nevladinog sektora i ponude obrazovnih programa određenim kategorijama odraslog stanovništva; „nestajanje” odraslih polaznika iz formalnog sistema obrazovanja na svim nivoima; haotično stanje u obrazovnoj ponudi odraslima (puno toga se nudi, ne zna se šta ko nudi, ne postoje podaci o kvalitetu ponude); pojava novih organizacionih oblika obrazovnog rada sa odraslima, programa i načina rada; reformski procesi u oblasti osnovnog i stručnog obrazovanja odraslih; dugogodišnja nastojanja da se donese Zakon o obrazovanju odraslih, koji je konačno donet 2013. godine.

Neopravdano bi bilo međuodnos različitih dešavanja u srpskom društvu i obrazovanja odraslih u Srbiji jednostrano svesti samo na negativan uticaj zbivanja u širem kontektu na obrazovanje namenjeno odraslima. Valja imati na umu da su se ova krizna zbivanja pojavljivala, dakle, i kao uzrok negativnih trednova i stagniranja u oblasti obrazovanja odraslih, ali i kao okidač za pozitivne promene i reformske procese. Obrazovanje (odraslih) se često posmatralo i kao jedan od faktora koji su doprineli usložnjavanju određenih problema, kao što je, na primer, nezaposlenost, a s druge strane i kao faktor u funkciji daljeg razvoja i prevazilaženja problema, opet i u ovom slučaju, nezaposlenosti, zatim smanjenja siromaštva, privrednog oporavka, poboljšanja kvaliteta života ljudi u starosti itd. Obrazovanje (odraslih) svakako jeste oblast od koje se, bar deklarativno, očekuju brojni pozitivni efekti u odnosu na najveće probleme srpskog društva.

\section{Nezaposlenost starijih odraslih u Srbiji - statistički pokazatelji}

Visok procenat registrovane nezaposlenosti je problem sa kojim se Srbija suočava već više decenija unazad. Od osamdesetih godina prošlog veka procenat nezaposlenih otpočeo je svoj rast od 15\% ka 20\% (Pejatović, 2006). U aprilu 2013. godine ovaj procenat iznosio je $24.1 \%$, a krajem septembra te godine, nezaposlenih osoba bilo je 759.372, od kojih je 25,27\% u kategorijama starosti od 50 do 64 godine (Nacionalna služba za zapošljavanje, 2013).

Prema podacima iz Ankete o radnoj snazi iz oktobra 2012. godine, stariji od 50 godina su, prema osnovnim statističkim indikatorima, uz kategoriju 
mladih, jedna od najranjivijih grupa. Posmatrajući ukupno stanovništvo u radnoj dobi (15-64 godine), osobe starosti 50-64 godine imaju i veću stopu neaktivnosti i manju stopu zaposlenosti (Republički zavod za statististiku, 2012).

Analiza podataka iz Ankete o radnoj snazi za period 2008-2012. pokazuje da je kriza najviše uticala na pogoršanje položaja mladih, zatim osoba sa nižim stepenom obrazovanja, kao i starijih osoba. U navedenom periodu stopa nezaposlenosti osoba sa nižim stepenom obrazovanja povećala se sa $13 \%$ u 2008. godini na $25,5 \%$ u 2012. Istovremeno, stopa nezaposlenosti starijih radnika (od 50 i više godina starosti) je udvostručena sa $8,2 \%$ na $16,2 \%$. Nižom u odnosu na opštu stopu nezaposlenosti čini je relativno mali procenat stanovništva radnog uzrasta ove starosne grupe koji su u potrazi za poslom. U ukupnoj populaciji starijih osoba (50-64 godine) oko 8\% je nezaposlenih, oko $40 \%$ su zaposleni, a preko 50\% neaktivni (Republički zavod za statististiku, 2009, 2010, 2012).

Podaci prezentovani u Studiji o životnom standardu u Srbiji nesumnjivo upućuju na zaključak da je nivo obrazovanja ,,jedan od najvažnijih faktora koji opredeljuju ekonomski položaj zaposlenih" (Vukmirović, D, Govoni, R. S, (Eds), 2008: 120). Međutim, i kada su zaposlene, takav status starijih osoba prate određene teškoće. Oko 55\% zaposlenih starijih radi za platu kod poslodavca, oko $13 \%$ su samozaposleni ili vlasnici radnje, oko $20 \%$ su poljoprivrednici, a oko $10 \%$ se svrstava u kategoriju - pomažući članovi domaćinstva. Visok procenat „ranjive” zaposlenosti starijih osoba dopunjuje i podatak o njihovoj velikoj angažovanosti u neformalnoj ekonomiji. Prema podacima iz pomenute Studije oko $40 \%$ starije populacije zaposlenih radilo je u neformalnoj ekonomiji, što je znatno više u odnosu na ukupno stanovništvo (ibidem).

Kao što možemo da vidimo, iz prezentovanih statističkih podataka, starije osobe imaju nepovoljniji položaj na tržištu rada i kada su zaposlene i kada nisu. Nazaposlene osobe starije životne dobi svakako prate i druge brojne životne neprilike, koje nastupaju umrežene sa nezaposlenošću. Između ostalog, među navedenim statističkim pokazateljima se mogu pronaći i razlozi naše zainteresovanosti i opredeljenja za odabir uzorka za istraživanje, iz kojeg deo podataka u ovom radu prikazujemo i analiziramo. 


\section{Metodološki okvir istraživanja}

Naše istraživanje realizovano je u okviru projekta „Obrazovanjem ka zapošljavanju i aktivnom starenju", koji je trajao od novembra 2012. godine do februara 2014. godine. Cilj čitavog projekta bio je da se pruži doprinos unapređivanju mera prevashodno obrazovnog karaktera, kao dela aktivnih mera tržišta rada, sa svrhom povećanja zaposlenosti i zapošljivosti odraslih osoba starosti 50 i više godina.

Cilj empirijskog dela istraživanja je da se ispitaju, s jedne strane, percepcija značaja obrazovnih mera za prevazilaženje problema nezaposlenosti i povećanje zapošljivosti, kao i spremnost ispitanika da učestvuju u obrazovnim aktivnostima i, s druge strane, promene u kvalitetu života starijih odraslih, koje se mogu pripisati uticaju dugoročne nezaposlenosti. Ovako fomulisani cilj omogućio nam je da direktno ispitamo, na osnovu odgovora ispitanika, odnos između obrazovanja odraslih i zapošljivosti i (ne)zaposlenosti, dok smo se indirektno ciljem istraživanja fokusirali na ulogu obrazovanja $u$ održavanju i unapređivanju kvaliteta života starijih osoba u kriznim životnim situacijama. Iz obilja prikupljenih podataka, ovom prilikom prezentovaćemo i proanalizirati deo rezultata koji se odnosi na dužinu nezaposlenosti, porodične i socijalne karakteristike ispitanika, kao i na percepciju značaja obrazovanja (odraslih) za prevazilaženje problema nezaposlenosti i spremnost ispitanika da se uključuju u organizovane obrazovne aktivnosti namenjene odraslima.

Za prikupljanje podataka u okviru ovog, deskriptivnog, istraživanja, korišćene su tehnike anketiranja i skaliranja. Za potrebe istraživanja, pripremljeni su upitnik i skale procene.

Anketiranje je obavljeno u pet gradova u Srbiji (Beograd, Niš, Novi Sad, Pančevo i Kragujevac), u saradnji sa Nacionalnom službom zapošljavanja. Uzorak istraživanja obuhvata 387 ispitanika starosti od 50 do 65 godina, različitog pola, obrazovnog nivoa i dužine nezaposlenosti.

Istraživanje je pokrenulo Društvo andragoga Srbije, uz finansijsku podršku Fondacije za otvoreno društvo Srbija.

Pri obradi podataka prikupljenih u istraživanju, korišćene su statističke procedure utvrđivanja frekvencija, procenata i aritmetičkih sredina. 


\section{Prezentovanje i analiza rezultata istraživanja}

\section{Nezaposlenost, porodični i socijalni kontekst ispitanika}

Kako pokazuju brojna istraživanja i iskustva evropskih zemalja, nezaposlenost starijih odraslih prerasta $\mathrm{u}$ visokom procentu u dugoročnu, sa svim pratećim posledicama - slabijom konkurentnošću na tržištu rada, osiromašenjem, zdravstvenim problemima i isključivanjem iz socijalnih tokova (Šverko, Galić, Seršić, 2005; Marić, 2005). Rezultati istraživanja fenomena siromaštva u Srbiji upravo izdvajaju nezaposlenost i neaktivnost kao glavne uzroke siromaštva i socijalne isključenosti (Vuković, Arandarenko, 2011). Mada analize pokazuju da su mladi na tržištu rada u Srbiji pod uticajem ekonomske krize postali najranjivija grupa, osobe od 50 do 65 godina starosti ispoljavaju takođe elemente ranjivosti, posebno kada se starosne karakteristike „udruže” sa nižim obrazovnim i materijalnim statusom (ibidem).

Slika porodičnih prilika, socijalne uključenosti i prirode nezaposlenosti naših ispitanika, posmatrana u tom svetlu, odražava veoma slične tendencije i rizike u odnosu na perspektive starijih odraslih za rešavanje problema nezaposlenosti, odnosno poboljšanje vlastitog i porodičnog statusa.

Porodični kontekst - broj članova domaćinstva, zaposlenih i nezaposlenih

\section{Slika 1.: Struktura domaćinstava ispitanika}

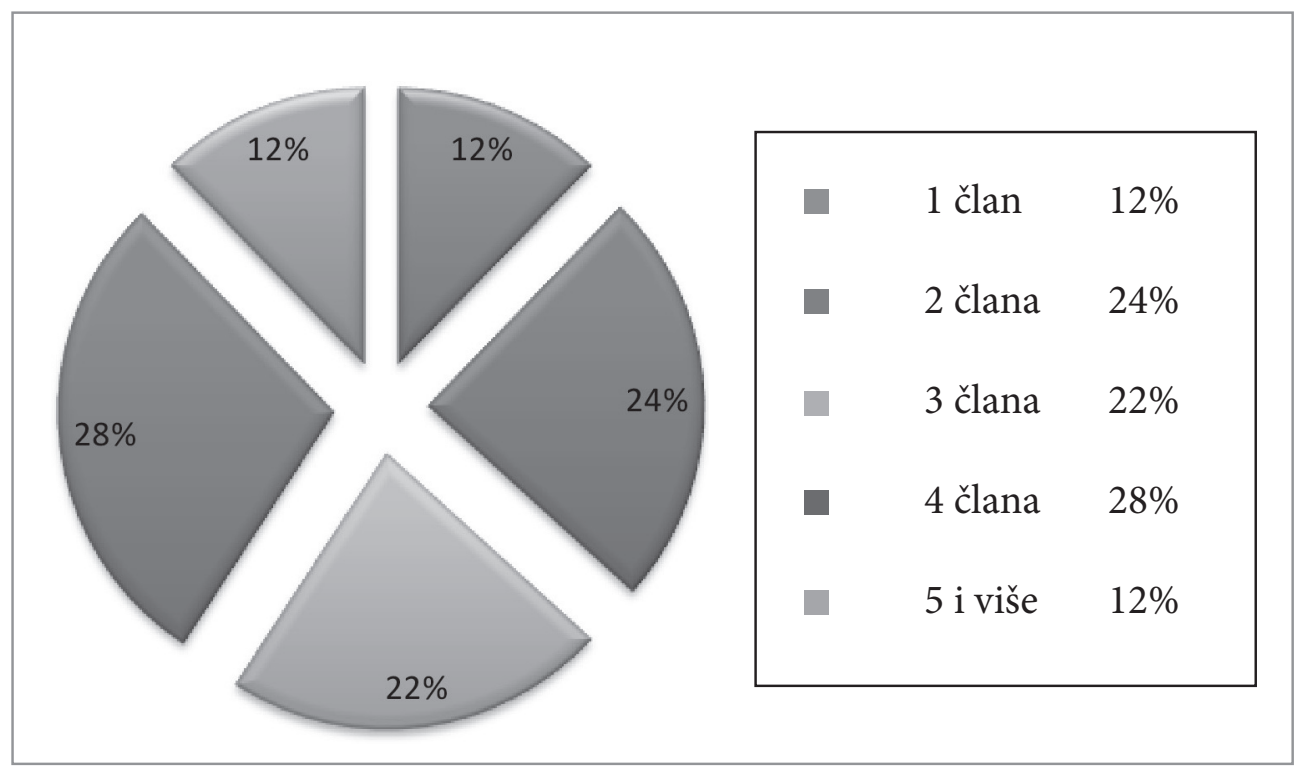


Kako pokazuje prethodna slika, shodno uobičajenoj strukturi u Srbiji, najveći broj ispitanika živi u četvoročlanim porodicama. Podatak o tome da čak njih $12 \%$ živi u porodicama od pet i više članova je donekle atipičan za ovu sredinu, a istovremeno predstavlja i mogući pokazatelj daljih problema: otežanog materijalnog statusa porodice, nepovoljnih uslova za rast i razvoj najmlađih članova, a samim tim i dalje moguće reprodukcije siromaštva i nezaposlenosti. Takođe je od značaja i podatak da 47 osoba obuhvaćenih našim istraživanjem (12\%) žive same, što, za sve među njima koje nemaju socijalna primanja, a imajući u vidu preovlađujuću dugoročnu nezaposlenost, verovatno znači da im glavni izvori prihoda leže u povremenim neprijavljenim poslovima ili dolaze od članova šire porodice, kako to jedan deo njih eksplicitno i napominje.

Pored navedenih problema, situacija se usložnjava i usled podatka koji pokazuje da u odnosu na ukupan broj, čak u 40\% slučajeva, naši ispitanici žive u porodicama u kojima nema zaposlenih članova! Gotovo $\mathrm{u}$ istom procentu (41\%), radi se o zajednicama koje imaju samo jednog zaposlenog člana. Imajući u vidu da, kako smo napomenuli, socijalnu pomoć ne prima većina naših ispitanika, a da je ona i u slučajevima kada se prima veoma niska i nedovoljna da pokrije čak i osnovne egzistencijalne troškove, težina ovakvog stanja očigledno narasta.

Ovde predstavljeni podaci izabrani su iz šireg fonda rezultata istraživanja, sa namerom da približe profil naših ispitanika i ocrtaju kontekst u kome je jedino moguće razumeti karakteristike njihovog statusa, navike i stavove pre svega prema potencijalu obrazovanja da im ponudi mogući izlaz iz krizne situacije, čiji je dominantan element svakako nezaposlenost.

\section{Učešće u kulturnim, rekreativnim i socijalnim aktivnostima}

\section{Tabela 1.: Rang-lista tipova mesta na kojima su ispitanici proveli poslednji (letnji) godišnji odmor}

\begin{tabular}{|c|l|c|}
\hline Rang & \multicolumn{1}{|c|}{ Tip mesta } & Frekvencije \\
\hline 1. & Kod kuće & 254 \\
\hline 2. & U neturističkom mestu u zemlji & 55 \\
\hline 3. & U inostranstvu & 42 \\
\hline 4. & U turističkom mestu u zemlji & 35 \\
\hline
\end{tabular}


U takvom kontekstu, ni gore predstavljen podatak po kome više od $60 \%$ starijih odraslih bez redovnog posla, obuhvaćenih našim istraživanjem, leto (godišnji odmor) provodi kod kuće, ne iznenađuje, ali zabrinjava. Manje od $10 \%$ njih uspeva da organizuje sebi odmor u nekom od turističkih mesta $u$ zemlji, dok ostali to čine u inostranstvu (10,88\%), odnosno neturističkom mestu u zemlji (14,24\%). Imajući u vidu njihov materijalni status i ukupnu socijalnu strukturu, možemo pretpostaviti (s obzirom na to da ove navike nisu ovde detaljnije istraživane), da je odlazak u inostranstvo, kao i u neturistička mesta u zemlji, zapravo povezan, u najvećem broju slučajeva, sa posetama rođacima i prijateljima, a ne sa korišćenjem turističkih aranžmana, odnosno sa zadovoljavanjem vlastitih interesovanja i provođenjem slobodnog vremena u skladu sa ličnim i porodičnim potrebama.

\section{Tabela 2.: Rang-lista frekventnosti upražnjavanja određenih kulturno-zabavno-rekreativnih sadržaja}

\begin{tabular}{|c|l|c|c|}
\multirow{2}{*}{ Rang } & \multirow{2}{*}{ Kulturno-zabavno-rekreativni sadržaji } & \multicolumn{2}{|c|}{ frekvencije } \\
\cline { 3 - 4 } & & Posećuje & Ne posećuje \\
\hline 1. & Prijatelji & 370 & 17 \\
\hline 2. & Kafane & 159 & 228 \\
\hline 3. & Sportske priredbe & 121 & 266 \\
\hline 4. & Pozorišta & 112 & 275 \\
\hline 5. & Bioskopi & 103 & 284 \\
\hline 6. & Koncerti rok, pop i narodne muzike & 81 & 306 \\
\hline 7. & Koncerti klasične muzike & 50 & 337 \\
\hline
\end{tabular}

I drugi podaci koji govore o načinu provođenja slobodnog vremena jasno pokazuju da je izbor kulturno-zabavnih i rekreativnih sadržaja naših ispitanika izuzetno skučen i specifičan. Mada odlike mentaliteta i navika svakodnevice u Srbiji određuje očigledno viši rejting kafana u odnosu na sportske i kulturne manifestacije, iza frekvencije korišćenja omiljenih izabranih kulturnih i sportskih sadržaja, kada se posmatraju pojedinačno, stoje i drugi razlozi. Najmanji broj ispitanih je u prilici da ih praktikuje redovno, a najveći broj po pravilu to uspeva samo par puta godišnje. Za opadanje ukupnog broja konzumenata koncerata verovatno jesu odgovorne kulturne preferencije i navike, ali za učestalost unutar svake kategorije razloge treba potražiti i 
u materijalnim (ne)mogućnostima starijih nezaposlenih osoba. Podatak da frekvencija poseta prijateljima prednjači u svakom pogledu (ukupan broj poseta i učestalost poseta), podstiče na nekoliko mogućih tumačenja: najpre, posete prijateljima nisu skup oblik provođenja slobodnog vremena; zatim, makar kod osoba nižeg obrazovnog nivoa, možemo pretpostaviti da su kulturne potrebe i navike takođe manje razvijene; pored toga, povlačenje jednog broja nezaposlenih, posebno kada taj status duže traje, iz većine krugova javnog života, verovatno je povezan sa ovim podatkom i potrebom da se u prijateljskom krugu, ljudi sličnih sebi, potraži podrška i zaklon od suočavanja sa nemogućnošču učešća u javnom kulturnom i društvenom životu.

Nedovoljna participacija u socijalnom životu nezaposlenih, posebno karakteristična za strukturu niže obrazovanih i siromašnijih, reflektuje se i kroz podatak prema kome čak $72 \%$ ispitanih ne pripada ni jednoj organizaciji civilnog društva, niti je član neke od političkih partija i drugih udruženja. Preostali udeo ispitanika kao kanal svog umrežavanja najviše pominje kulturno-umetnička društva, nevladine organizacije ili, ređe, političke partije.

Jedan od ključnih pokazatelja statusa naših ispitanika i jedno od centralnih pitanja kojima smo okrenuti u ovom radu jeste dužina njihove nezaposlenosti. $\mathrm{Na}$ sledećoj slici predstavljeni su podaci dobijeni na našem uzorku, kao odgovor na pitanje o tome koliko meseci, odnosno godina traje njihova nezaposlenost:

\section{Slika 2.: Dužina trajanja nezaposlenosti ispitanika}

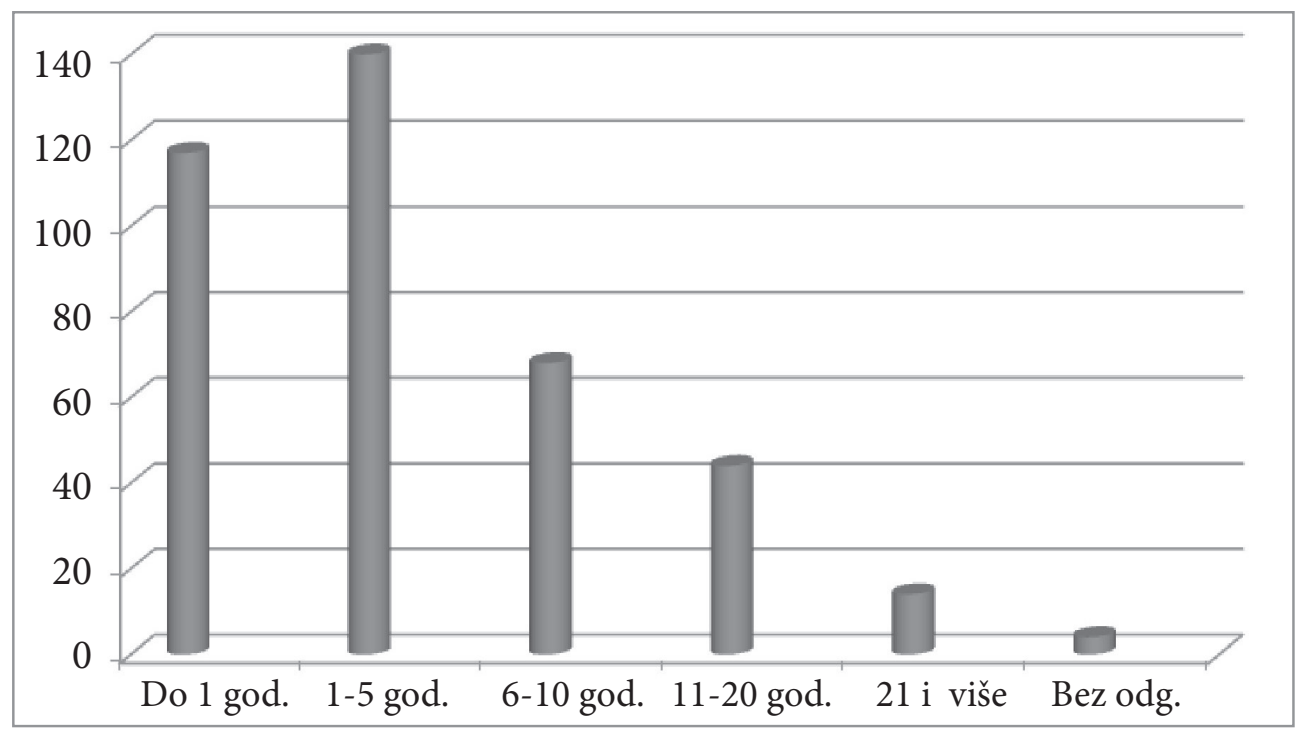


Kako je prethodno predstavljeno, među ispitanicima preovlađuju osobe koje su bez posla više od jedne do pet godina u kontinuitetu $(36,27 \%)$. Uključujući ovu skupinu, uz sve ostale osobe koje su bez posla i duže od 5 godina, dolazimo do podatka da čak 68,91\% starijih nezaposlenih koji su učestvovali u ovom istraživanju pripada kategoriji dugoročno nezaposlenih (godinu dana i više).

Ove podatke potvrđuje i dodatno pojašnjava analiza zvanične evidencije „Ankete o radnoj snazi” u Srbiji za period od 2008. do 2012. godine. Naime, ova, kao i većina drugih analiza relevantnih za stanje u Srbiji, jasno pokazuju da je učešće dugoročne i veoma duge nezaposlenosti (preko dve godine) u grupi starijih od 50 godina osetno veće u odnosu na ukupnu populaciju nezaposlenih. Takođe, pominjani podatak da ovu skupinu nije najviše ugrozila kriza koju Srbija deli sa evropskim zemljama od 2008. godine, uz sliku dugoročne nezaposlenosti, očigledno upućuje na druge razloge zbog kojih je većina ove starosne grupe ostala bez posla. Oni su pre svega, potvrđuje se i ovde, za čak $70 \%$ ljudi starijih od 50 godina, u efektima produžene tranzicije, odnosno „restrukturiranja privrede” - likvidacije i stečaja preduzeća, što je zaposlene drugih starosnih grupa ,pogodilo" u osetno manjem, mada ne zanemarljivom procentu od 57\% (Republički zavod za statistiku i informatiku, 2008-2012). Isti izvor navodi da samo 4\% nezaposlenih iz ove starosne skupine nema nikakvo radno iskustvo, što takođe pokazuju i podaci našeg istraživanja prema kojima, u grupi osoba koje su nezaposlene više od 20 godina, ima njih 3,62\%. Imajući u vidu da je među njima i nekoliko osoba koje ne rade više od 30 godina (najduži zabeleženi „staž nezaposlenosti” je 40 godina), a prateći ove odgovore u odnosu na širu sliku koju nam pruža naše ukupno istraživanje, izgleda da se oni koji nikada nisu radili (pretežno iz zdravstvenih ili porodičnih razloga), zapravo „kriju” u ovoj kategoriji.

Pored ovih, u podacima koji se odnose na dugoročnu nezaposlenost i naših ispitanika, prepoznajemo još jednu važnu karakteristiku ove populacije. Sudeći prema rezultatima niza istraživanja i analiza, kod onih koji pripadaju ovoj grupi, dolazi često do odustajanja od dalje potrage za poslom, te je pre reč o neaktivnosti nego nezaposlenosti u pravom smislu te reči. Poredeći stepen neaktivnosti nezaposlenih u pogledu traženja posla prema starosti, rezultati više istraživanja u Srbiji pružaju veoma zabrinjavajuću sliku: sa starenjem drastično raste neaktivnost, pa tako u starosnom intervalu od 40 do 50 godina gotovo polovina, a u periodu između 50 i 65 godina čak $90 \%$ nezaposlenih prestaje da aktivno traži posao. Istovremeno, kako govore rezultati istraživanja ovih autora, takođe kod 90 od 100 starijih nezaposlenih 
(od 50 godina), značajno opada i očekivanje da će u skoroj budućnosti naći posao (CESID, 2010, prema Mihailović i Mihailović, 2011).

Pre nego što pokazatelje i moguće uzroke obeshrabrenosti prikažemo i kroz neke od odgovora naših ispitanika, navešćemo nekoliko mogućih uzročnika ovakve slike o kojima govore i drugi autori, odnosno zvanični podaci o nezaposlenosti u Srbiji.

Mada su česte polemike o tome da li zaista postoji starosna diskriminacija pri zapošljavanju, odnosno da li su pritom više marginalizovani mladi ili stariji, rezultati nekih novijih socioloških istraživanja u Srbiji ipak upućuju na ugrožavanje prava starijih radnika na zaposlenje. Prema ovim nalazima, čak svaki drugi stariji nezaposleni doživljava diskriminaciju u pokušajima da nađe posao (CESID, 2009, prema Mihailović i Mihailović, 2011).

Uporedo sa tim, objektivno zastarevanje znanja i veština zaposlenih u odnosu na potrebe tržišta rada, proizvod je takođe niza činilaca koji deluju u sinergiji. S jedne strane, pritisak tranzicije uz tradicionalno gledanje na starije radnike kao na slabije sposobne za učenje i sticanje novih veština, sa sobom nosi ne retku procenu poslodavaca da u njih nije isplativo ulagati. Nije retka pojava da se ovakve procene zasnivaju ne samo na ovoj već i bojazni da će čak i uspešno usvojena znanja i veštine stariji radnici koristiti kraće u odnosu na mlađe grupe uposlenika.

Dodatni rizik po zapošljavanje starijih nosi njihov relativno nizak obrazovni status: $40 \%$ pripadnika ove skupine ima osnovno i nepotpuno osnovno obrazovanje, $51 \%$ srednje, a više i visoko obrazovanje njih $9 \%$, dok je broj najniže obrazovanih u porastu sa godinama starosti (Nacionalna služba zapošljavanja, 2011-2012).

\section{Slika br. 3: Obrazovna struktura starijih nezaposlenih}

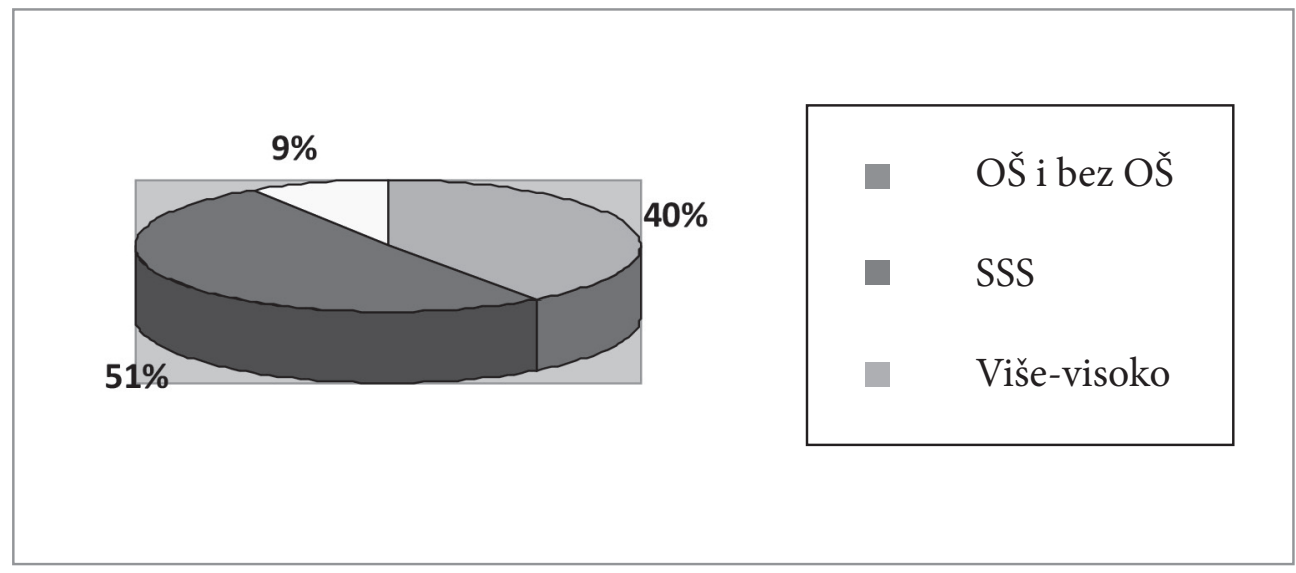


Nešto manje od trećine naših ispitanika (30,31\%) posao traži kraće od godinu dana, a najkraći period nezaposlenosti evidentiran ovim podacima je mesec dana. Otpuštanje starijih radnika, sudeći i prema ovom podatku, teče u kontinuitetu. O tome govore i sledeći pokazatelji: prema evidenciji Nacionalne službe zapošljavanja, godišnje se zaposli 196.000 starijih nezaposlenih, a upravo toliko biva i prijavljeno na evidenciju ove službe $u$ istom intervalu; među onima koji se zapošljavaju iz ove skupine je pritom tri puta više osoba sa visokim obrazovanjem, u odnosu na ukupan broj osoba. (Nacionalna služba zapošljavanja, 2009-2012).

Istražujući uticaj dugoročne nezaposlenosti na ostale elemente procesa socijalnog isključivanja - ekonomsku deprivaciju i socijalnu izolaciju - kao i verovatnost zapošljavanja na uzorku nezaposlenih u Hrvatskoj u dva navrata (2003. i 2004. godine), autori, pored ostalog, potvrđuju udeo obrazovanja u porastu šansi za zapošljavanje. Na uzorku od 601 učesnika istraživanja, koji su bili nezaposleni u prvom ispitivanju, 207 je uspelo da se zaposli a analizom njihovih karakteristika, ova longitudinalna studija pokazuje da su šanse osoba viših obrazovnih nivoa da se zaposle čak četiri puta veće od osoba sa osnovnom ili nepotpunom osnovnom školom (Šverko, Galić, Seršić, 2005), te je očigledno da se obrazovanje pojavljuje kao najsnažniji činilac predikcije zapošljavanja, kao i izlaženja iz kruga socijalne izolacije.

Upravo istraživanje značaja obrazovanja viđenog očima nezaposlenih i njihova spremnost da se uključe u obrazovne programe zarad povećanja zapošljivosti čine poseban fokus našeg istraživanja.

\section{Odnos prema obrazovanju i spremnost na učešće u obrazovnim programima}

Izražavajući spremnost da participiraju u nekom od ponuđenih oblika obrazovanja, odnosno procesu verifikacije prethodnog znanja, stariji nezaposleni iz našeg uzorka su se najpre odlučivali za akreditovanu obuku nakon koje bi stekli sertifikat, a zatim za uključivanje u proces verifikovanja prethodno stečenih znanja, iza čega slede ostali ponuđeni i u donjoj tabeli predstavljeni načini sticanja i/ili verifikacije znanja i veština: 


\section{Tabela br. 3: Rang-lista obrazovnih aktivnosti na osnovu spremnosti starijih nezaposlenih da se u njih uključe}

\begin{tabular}{|c|l|c|} 
Rang & \multicolumn{1}{|c|}{ Obrazovne aktivnosti } & $\begin{array}{c}\text { Spremnost da se u } \\
\text { aktivnost uključe - AS }\end{array}$ \\
\hline 1. & Završetak akreditovane obuke sa sertifikatom & 2.96 \\
\hline 2. & $\begin{array}{l}\text { Uključivanje u proces verifikovanja na osnovu } \\
\text { (radnog) iskustva stečenih znanja i veština - } \\
\text { polaganje ispita }\end{array}$ & 2.89 \\
\hline 3. & $\begin{array}{l}\text { Završetak određene škole, odnosno formalno } \\
\text { povećanje nivoa obrazovanja (stepena } \\
\text { kvlifikacije) i dobijanje diplome }\end{array}$ & 2.34 \\
\hline 4. & $\begin{array}{l}\text { Završetak neakreditovane obuke sa } \\
\text { sertifikatom }\end{array}$ & 2.31 \\
\hline
\end{tabular}

S obzirom na životno doba naših ispitanika, ne čudi što su dalje formalno obrazovanje i sticanje diplome njima manje prihvatljivi - kao dugotrajniji i manje praktičan način za dolaženje do potrebnih znanja i veština. Ponovno „vraćanje u školu”, takođe, može se posmatrati kao neadekvatno, posebno usled uticaja pominjanih stereotipa o starijima kao „manje sposobnima za učenje” i onima koji bi ,pre trebalo da razmišljaju o penzionisanju nego o svom daljem obrazovanju".

Imajući u vidu tek nedavno zakonski pruženu mogućnost priznavanja prethodno stečenog znanja, koja u Srbiji još uvek u praksi nije zaživela, popularnost ovog izbora od strane naših ispitanika možemo najpre pripisati njihovom nedovoljnom poznavanju ovog procesa i pretpostavci da je to kratkotrajnija i manje zahtevna, a od društva prepoznata kao legitimna, aktivnost u poređenju sa daljim sticanjem formalnih stepena ili programima koji nisu akreditovani u našoj sredini.

Procenjujući moć obrazovanja da poveća njihove izglede za zapošljavanje, na skali od 1 do 5, ubedljivo najmanji broj ispitanika (36 od 387) smatra da obrazovanje svakako može da pomogne, dok njih najviše, gotovo polovina (153), veruje da bi ono možda tome moglo i doprineti (AS za čitav uzorak = 2.68). 
Slika br. 4: Procena značaja obrazovanja u rešavanju problema nezaposlenosti

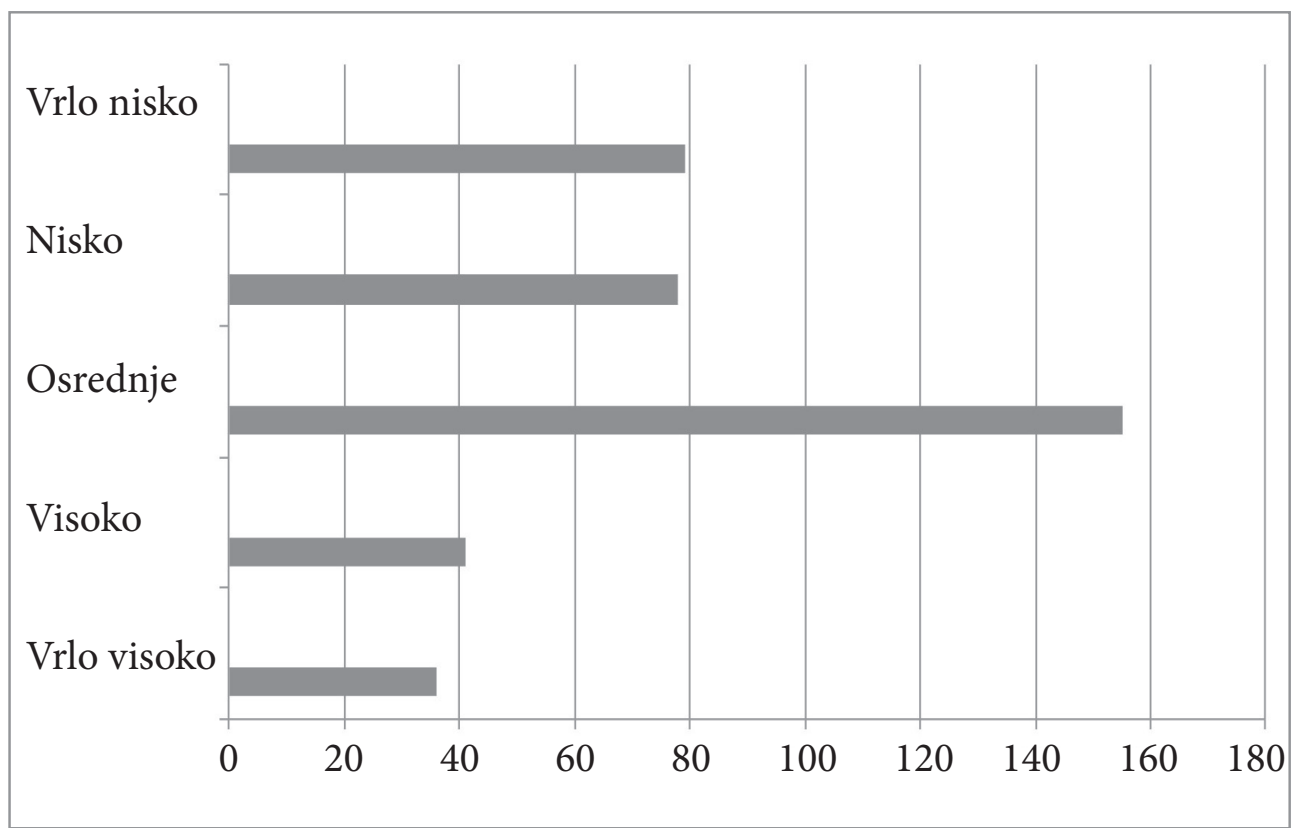

Imajući u vidu karakteristike položaja i dugoročnost nezaposlenosti starijih uopšte, pa i u našem uzorku, možemo pretpostaviti da na ovakav stav i spremnost na obrazovanje deluje opšta obeshrabrenost, koja u sebi sadrži nekoliko sastavnih elemenata: bojazan niže obrazovanih da se pored mlađih i obrazovanijih teško mogu boriti za zaposlenje; razočaranost visoko obrazovanih nad činjenicom da nisu u dovoljnoj meri konkurentni na tržištu rada, a, pored ovih, subjektivnih, verovatno je da se ovde „umešalo” i nezadovoljstvo objektivnom ponudom obrazovnih programa i mogućnostima namenjenim ovoj specifičnoj grupi. Dodamo li ovim mogućim razlozima i pretpostavljenu nerazvijenost i neartikulisanost obrazovnih potreba i nedovoljnu spremnost za participaciju kod osoba nižih nivoa obrazovanja među našim ispitanicima, navedeni podaci zapravo, ne iznenađuju.

Slične trendove reflektuju i rezultati niza istraživanja, među kojima izdvajamo sledeći: istražujući stav prema obuci za traženje posla, autori navode da je na ukupnom uzorku, 36\% nezaposlenih zainteresovano, dok se u poduzorku starijih (od 50 godina) ovaj udeo smanjuje na $20 \%$ - i to pod uslovom da obuka bude besplatna (Mihailović i Mihailović, 2011). 
Slabija participacija starijih u programima obrazovanja prisutna je kao trend u većini evropskih zemalja. Kao jedan od razloga tome navode se i slabija profesionalna mobilnost starijih, a posebno geografska. Takođe, iskustvo starijih osoba i u ovom slučaju može delovati u dva pravca: kao prednost $u$ odnosu na potencijalni kvalitet rada mlađih, ali i kao barijera za preduzimanje sticanja ili usavršavanja znanja i veština (European Commission, 2003).

Izdvajanja Nacionalne službe zapošljavanja u Srbiji za programe obuke u sklopu aktivnih mera za podsticaj zapošljavanja jesu konstantna, mada nedovoljna. Efekti ekonomske krize od 2008, zajednički i Srbiji, ne tretiraju se, međutim, na isti način: za razliku od većine zemalja EU, pogoršanje situacije na tržištu rada najčešće ne prati povećanje ovih izdvajanja. Tako na primer, zbog ograničenja u budžetu za 2013.godinu ionako skromna sredstva za aktivne mere su smanjena sa 3,4 na 1,2 milijarde dinara (0,033 BDP-a), iako je stopa nezaposlenosti sa $24,6 \%$ u 2012, u aprilu 2013. porasla na preko 25\% (Republički zavod za statistiku i informatiku, 2013).

Uprkos ovim nedostacima politike i prakse podsticaja ublažavanju nezaposlenosti putem aktivnih mera, kao i u našem istraživanju prikazanom odnosu starijih nezaposlenih prema obrazovanju, njihova aktivnost na ovom planu, sudeći po još nekim rezultatima našeg istraživanja, ne izostaje u potpunosti.

Naime, upitani da li se kao nezaposleni samoinicijativno uključuju u obrazovne programe čiji organizator nije Nacionalna služba zapošljavanja, već neki drugi provajder, njih 15\% potvrđuje da takve aktivnosti preduzima, i stiče nova znanja i veštine, ponajviše u oblasti informatike i stranih jezika. Upravo ove oblasti prednjače i među odgovorima ispitanika na još jedno pitanje, o tome da li su kao nezaposleni samostalno sticali određena znanja i veštine, o čemu izveštava čak dvostruko više - 32\% od ukupnog uzorka. Sam izbor ovih oblasti nije naravno slučajan - imajući u vidu zahteve konkursa za ogromnu većinu radnih mesta, među kojima su po pravilu prisutna znanja i veštine iz oblasti informatike i stranih jezika, odluka da se investira upravo u njih svakako ne iznenađuje.

Posmatrajući ovde uočene tendencije i stavove starijih nezaposlenih, očigledno je da i pored njihove ograničene vere i spremnosti na učešće $u$ obrazovanju usmerenom ka rešavanju problema nezaposlenosti, naši ispitanici bilo sami bilo uz pomoć Nacionalne službe zapošljavanja i drugih provajdera stiču znanja i veštine iz oblasti u kojima osećaju najveći obrazovni deficit. Reč je upravo o domenima koji nisu neophodno vezani za stručne profile, već o bazičnim kompetencijama, poput informacionih tehnologija i stranih jezika. 


\section{Zaključna razmatranja}

Uporedo sa prevazilaženjem posledica „prolongiranog kriznog perioda”, dakle za srpsko društvo specifičnih problema dugotrajne tranzicije u svim sferama, teče i proces zajednički sa ostalim evropskim zemljama - suočavanje sa izazovima i efektima ekonomske krize. Problem nezaposlenosti je svakako i posledica i generator krize, a populacija starijih nezaposlenih jedna od najranjivijih grupa na tržištu rada.

Ovaj problem se uviđa i reflektuje na strateškom, akcionom i praktičnom nivou, a položaj starijih radnika - zaposlenih i nezaposlenih - u novije vreme pobuđuje pažnju istraživača i šire javnosti, i ne samo u Srbiji, već i u regionu, kao što smo videli iz nekih od u ovom radu navođenih rezultata drugih istraživanja.

Nacionalna strategija zapošljavanja prepoznaje značaj uključivanja starijih nezaposlenih u mere aktivnog zapošljavanja, posebno obuke za traženje posla, naglašavajući da je neophodno usmeriti podsticaje i ka poslodavcima, kako bi se obezbedilo veće zadržavanje starijih radnika na poslu, odnosno sprečila diskriminacija ove populacije pri zapošljavanju (Službeni glasnik, 2011). Slično tome, Nacionalna strategija o starenju naglašava važnost prilagođavanja tržišta rada socijalnim i ekonomskim posledicama starenja stanovništva, a posebno smanjivanja nezaposlenosti muškaraca i žena starijih od 45, odnosno 50 godina, pri čemu se podsticanje doživotnog učenja vidi kao osnovni preduslov veće participacije starijih na tržištu rada (Nacionalna strategija o starenju, 2006).

I pored obuhvata starijih odraslih (među kojima i dela naših ispitanika) programima obuke za traženje posla, prekvalifikacijom ili drugim obrazovnim vidovima i aktivnostima, Nacionalna služba za zapošljavanje se suočava sa smanjenjem sredstava za ovu namenu - upravo u vreme kada većina evropskih zemalja uvećava finansijska ulaganja u te mere. Uprkos predstavljenim strateškim opredeljenjima u Srbiji, kao i nizu empirijskih i praktičnih dokaza da stručno obučavanje, usavršavanje, kao i stečeni obrazovni nivo nezaposlenih direktno uvećava njihove šanse za zapošljavanje (Despotović, 1990; Šverko, Galić, Seršić, 2005), sprovođenje ovih mera u praksi je očito na udaru budžetskih rezova, usled stalnih kriznih turbulencija. To bi dalje moglo još nepovoljnije da se odrazi na inače nezavidan položaj starijih radnika i smanjenje njihove ionako nedovoljne participacije u programima obrazovanja za podsticaj zapošljavanja.

Sudeći prema iskustvima drugih evropskih zemalja, statističkim podacima i rezultatima istraživanja na području Srbije i regiona, obrazovanje može da 
ponudi izlaz iz začaranog kruga nezaposlenosti i socijalne izolacije starijim nezaposlenima - ukoliko je osmišljeno i organizovano u skladu sa njihovim potrebama i specifičnostima, a naravno i zahtevima tržišta rada, odnosno modernih vremena. Polazeći upravo od stavova i potreba starijih nezaposlenih, u našem smo istraživanju došli i do ovde kratko predstavljenih pokazatelja prema kojima postoji nedovoljna spremnost za uključivanje u obrazovne programe, odnosno vera da oni mogu da doprinesu zapošljavanju. Pored obeshrabrenosti ovih ljudi tokom dugogodišnje nezaposlenosti ili nerazvijenih i neartikulisanih obrazovnih potreba - naročito onih među njima na nižem obrazovnom nivou - među činiocima ovakvog stava je sigurno i nerazvijena lepeza obrazovnih programa, odnosno neprilagođenost postojećih programa njihovim potrebama i mogućnostima koje se ovoj specifičnoj populaciji nude na tržištu rada. O tome govore i podaci našeg istraživanja, čije detaljno predstavljanje prevazilazi okvire ovog rada, a prema kojima postoji dugačka lista veoma raznovrsnih oblasti u kojima bi naši ispitanici želeli da se dalje usavršavaju ili osposobljavaju, a koja se samo u svom manjem delu poklapa sa programima koji im se trenutno u Srbiji, kao nezaposlenima i zvanično prijavljenima na evidenciju Nacionalne službe zapošljavanja, nude.

Pokazuje se još jednom da se, kada sa deklarativnog nivoa i strateških opredeljenja o veri u obrazovanje i doživotno učenje krenemo ka praksi, suočavamo sa problemom očiglednog nedostatka sinergije i konkretnih podsticaja primeni promovisanih načela. Istraživanje čije smo odabrane rezultate predstavili u ovom radu upravo je pokrenuto sa ciljem skretanja pažnje na neophodnost da se promene dogode i na planu politike i prakse $u$ oblasti obrazovanja starijih nezaposlenih u Srbiji.

\section{ADULT EDUCATION - BREAKING THE CYCLE OF UNEMPLOYMENT AND SOCIAL ISOLATION OF ELDERS}

\section{- Abstract -}

Continued rise of unemployment, distinctive for many European societies today, is in Serbia additionally burdened by specific long-term crisis, heightened by the world economic crisis at the end of the last decade. The gap between strategic orientation towards lifelong education as a powerful mechanism of reduction of unemployment and practice is particularly evident when it comes to a group of older unemployed. 
Faced with these trends, experts gathered around the Society of Andragogues of Serbia launched in 2012 the project ,Education for employment and active aging", within the measures of active employment, with the aim to contribute to improvement of education in Serbia and to increase the employment and the employability of adults older than 50 years of age.

In this paper we present one segment of the results of the research conducted on a sample of 387 older unemployed in five cities in Serbia, aged 50-65, of different sex and educational status. Highlighted are findings about attitudes of unemployed towards educational opportunities which should lead them to employment and overcoming of unfavorable socio-economic status, mainly caused by long-term unemployment and gradual exclusion of social life. The observed trends are reviewed in the context of specific and global social circumstances and directions of necessary improvement of educational and other solutions at the level of policy and practice of (adult) education and employment.

Key words: unemployment, adult education, older adults, long-term unemployment of older adults.

\section{Literatura}

- Despotović, M, (1990), Obrazovanje odraslih $i$ dugoročna nezaposlenost u Jugoslaviji, studija slučaja, Beograd: Institut za pedagogiju i andragogiju Filozofskog fakulteta u Beogradu.

- European Commission, (2003), Employment in Europe, Luxemburg: Office for official publication of the European Communities.

- Marić, Z. (2005), Predikcija intenziteta i namere traženja posla na uzorku nezaposlenih, Psihologija, Vol. 38 (2), str. 1-15.

- Medić, S, Popović, K, Milanović, M, (2009), Razvoj i stanje obrazovanja i učenja odraslih u Srbiji - CONFINTEA VI - Šesta međunarodna konferencija o obrazovanju odraslih; Beograd: Društvo za obrazovanje odraslih (Beograd, Srbija), DVV International (Sarajevo, BiH); Sofija.

- Mihailović, S, Mihailović, V, (2011), Stariji radnici, Beograd: Centar za demokratiju.

- Nacionalna služba za zapošljavanje, Statistički podaci o prosečnom broju zaposlenih sa evidencije u periodu 2009-2012. 
- Nacionalna služba za zapošljavanje, (septembar 2013), Nezaposlenost i zapošljavanje u Republici Srbiji, Mesečni statistički bilten, Beograd, br. 133.

- Nacionalna strategija o starenju 2005-2016, Službeni glasnik RS, 55/05 i 71/05/ 2006.

- Nacionalna strategija zapošljavanja 2011-2020, Službeni glasnik RS, 37/2011.

- Pejatović, A, (2006), Obrazovanje i kvalitet života, Beograd: Institut za pedagogiju i andragogiju Filozofskog fakulteta u Beogradu.

- Program rasporeda korišćenja sredstava za 2013 godinu $\boldsymbol{i}$ za stopu nezaposlenosti za 2013 godinu, Saopštenje Republičkog zavoda za statistiku i informatiku o rezultatima ankete o radnoj snazi, april 2013.

- Republički zavod za statistiku, (2008), Anketa o radnoj snazi, Beograd.

- Republički zavod za statistiku, (2009), Anketa o radnoj snazi, Beograd.

- Republički zavod za statistiku, (2010), Anketa o radnoj snazi, Beograd.

- Republički zavod za statistiku, (2012), Anketa o radnoj snazi, oktobar 2012, Beograd.

- Šverko, B, Galić, Z, Maslić Seršić, D, (2006), Nezaposlenost i socijalna isključenost - longitudinalna studija, Revija za socijalnu politiku, god. 13, br. 1, str. 1-14, Zagreb.

- Vukmirović, D, Govoni, R. S, (Eds) (2008), Living Standards Measurement Study: Serbia 2002-2007, Belgrade: Statistical Office of the Republic of Serbia.

- Vuković, D, Arandarenko, M, (ur), (2011), Socijalne reforme - sadržaj i rezultati, Beograd: Univerzitet u Beogradu, Fakultet političkih nauka. 